\title{
The Managementof Community-Based Irrigation System (A Case Study of Water Users' (Farmers) Association in Suak, Manis Raya Village, Sepauk District, Sintang Regency)
}

\author{
Deni Ratnasari ${ }^{1}$, Zaenal Kusuma², Imam Hanafi ${ }^{3}$ \\ ${ }^{1}$ Post Graduate School of Environmental and Development, Graduate, Program, Brawijaya University \\ ${ }^{2}$ Soil Department, Faculty of Agriculture, Universitas Brawijaya, Malang, Indonesia \\ ${ }^{3}$ Department of Public Administration, Faculty of Administrative Sciences Universitas Brawijaya, Malang, Indonesia
}

\begin{abstract}
Water user farmer association (P3A) is an organization closely related to regulation of irrigation water in a tertiary or village plot service area formed by farmers or farmer groups in a democratic village. The role of P3A is to manage irrigation water and water distributors fairly and evenly in tertiary / stronger printing. The research aims to analyze the management of community-based irrigation system by P3A in Suak Village of Manis Raya Village of Sepauk Subdistrict of Sintang Regency and to Analyze the inhibiting factors in the management of irrigation system. The research was done by descriptive method and qualitative analysis. Data obtained from interviews, literature, and field observations, then analyzed and interpreted by giving conclusions. The results of the research indicate that (1) the institutional aspect, irrigation network in Suak sub village has no institution of water user farmer association (P3A), (2) HR aspect, farmer of Dusun Suak has adequate human resources seen from age, education, social economy and work ability. (3) Aspects of facilities and infrastructure, facilities and infrastructure of farmers in the village of Suak are still limited, farmers have not been able to utilize existing facilities and infrastructure. (4) Aspects of irrigation systems, farmers are still freely flowing water without regulation, irrigation maintenance is done when there is government funding, the main dam leaked for the last two years has not been fixed. Farmers' awareness of irrigation networks is not yet available. The inhibiting factor of irrigation system management is that there is no P3A institution yet, the participation of farmers is limited, the fund is limited. From the results of the research, irrigation management in the village of sweet is still not implemented maximally either from government or from society, seen from condition of irrigation network which often happened accumulation of garbage and weeds. In addition, community participation is still very poor. Irrigation management in the hamlet of Suak has not been well managed by the farmers either in the maintenance of irrigation networks, as well as the distribution of farmers' peat water because there is no P3A organization that regulates irrigation management and water distribution. Irrigation management can be sustainable should the cooperation between stakeholders.
\end{abstract}

Keywords: Farmers' Participation, Irrigation System Management, P3A

\section{INTRODUCTION}

Water is a natural resource that is very useful and has big potential in human life and other living things. This can be said that water is the source of life on earth. The demand for water continues to rise from time to time which can be caused by the growth of population, the increase of society's income, and the development of all fields. Therefore, the use of water for an irrigation should be done appropriately. From the observations in this research, there are many water and irrigation systems that have been built but not yet fully utilized by the community due to the non-functioning of tertiary water management containers known as water user

\footnotetext{
Correspondence address:

Deni Ratnasari

Email : deniratnasarisemadai@gmail.com

Address : Tanjung Bunga Kecamatan Kayan Hulu Village, Sintang District, West Kalimantan, 78694
}

farmer associations (P3A). One of the key factors of successful irrigation water utilization is determined by the active role of P3A. With the active role of $\mathrm{P3A}$, it will increase the effectiveness and efficiency of water utilization in which it will automatically produce maximumproduction. The development and management of irrigation system will greatly assist the water users (farmers) to meet the needs of thepaddy fields. A good system of irrigation will improve the function of the irrigation system itself so that the flow of the water from upstream to paddy fields will not experience obstacles [1].

The irrigation systems in Sepauk district are not well managed by the government and the community where 17 of which are dysfunctional. Many of those irrigation systems are placed in a wrong location as in Suak, Manis Raya Village. In Suak, the management of the irrigation system is 
currently done by the farming communities who own paddy fields around the irrigation system. It is known that the Water Users' (Farmers) Association or P3A which was formed in 1982 do not work for the community. realizing an institution to be acceptable to society and able to build the participation of its members depends on the quality of leadership, alignment between members with village apparatus, incentives from yields which determines organizational capability, as well as transparency and democracy in organization which will support organizational performance [2].

The existence of active and independent P3A is highly necessary not only for irrigation management but for the preservation of irrigation system function. P3A is very closely related to water regulation, but, the delegation of authority to P3A organization in managing irrigation system has not been implemented well until now. Of all villages in Sepauk District, there is only one irrigation system equipped with P3A organization which is in Bedayan Village. Irrigation in the bedayan village is also not functioning properly because the construction is lower position, while the farmer's rice position is higher. Irrigation is not used even now the irrigation is hit by large wood, and suffered damage and many tools are missing. Rice farmers in the village of Bedayan use rain-fed.Developing P3A for irrigation management requires communication, coordination, and cooperation among stakeholders. Weak communication and coordination might cause failure in such irrigation system. function and role of institutional P3A is as manager of irrigation water and irrigation water distributors equally in tertiary / stronger printing. As a local wisdom, P3A institutions need to be conserved because their culture and social values can strengthen the capacity of P3A management, so that they are empowered and motivated and motivate the awareness of water user farmers to know, willing and able to conduct activities related to the maintenance and management of irrigation water [3]. To realize the orderly management of irrigation networks built by the government, an irrigation management institution was established. The institutions of irrigation management include government agencies in charge of irrigation, water user farmer associations, and irrigation commissions [4].

The water supply for paddy fields in Suak, Manis Raya Village will experience a shortage due to the inefficient utilization. The leaking and shallowness of the dam in the past two years have not been noticed by the government. Therefore, it is expected that P3A organization can be responsible for the sustainability of irrigation system by giving a report when a damage occurs. P3A is assumed to guarantee the availability of irrigation water and the fairness in its distribution. P3A also has the function to maintain the irrigation system as well as build social values sourced from local wisdom. There is another problem in the management of irrigation system which is the poor participation of the community. This can be seen from the attitude of the people who are less concerned with the sustainability of the system, the behavior of the farmers which believe that water is free resources, and the lack of possession sense towards the irrigation system. The neglected irrigation network causes the already built infrastructure to not function as planned and the irrigation network is prematurely damaged / the age of the building so as to require large network rehabilitation costs. Water supply through irrigation is a solution that can overcome the lack of water for agricultural and household purposes. Water User Farmers Association (P3A) has the right and obligation to manage the tertiary irrigation networks. Farmer community participation as one of the factors supporting the success of irrigation development programs, it can be ascertained that community participation will be obtained if the programs in development really fit with the needs of the community [5]. described that the success of agricultural sector development should be supported by all stakeholders, both the government and community. Such participation is absolutely necessary for a successful, beneficial, and sustainable development [6].

The main problem arising from the irrigation management in the Dusun Suak village Manis Raya is the concern of the community, local government and village government against the network is still very less. To answer the problem, the researcher conducted a study related to the management of community-based irrigation system in the hamlet of Suak village manis raya village in the district of Sintang. The purpose of this research are (1) Analyzing community-based irrigation management in Dusun Suak village Manis Raya, (2) analyzing the inhibiting factors of irrigation management in Dusun Suak Desa Manis Raya. 


\section{RESEARCH METHODS}

The research method used is a descriptive method with qualitative analysis approach. Through qualitative research approach, it is hoped that the researcher will be able to comprehensively describe the problems studied in relation to the management of community based irrigation system. Another consideration underlying the use of qualitative approaches, is that qualitative research presents a thorough form in analyzing a phenomenon. Qualitative research method is a research method based on positivism philosophy, used to examine the natural object condition where the researcher is as a key instrument, sampling of data source is done by purposive sampling, collecting technique with triangulation (analysis) data is inductive / qualitative, and qualitative research results further suppress the meaning of the generalization by describing the state of objects and subjects in the present with the facts that exist [7]. The data were primary data and secondary data and obtained by using interview guidelines, observation, and documentation review. The focus of this research is the institutional aspects, facilities and infrastructure aspects, human resources aspects, irrigation system aspects, farmer participation, and factors that affect the management of irrigation system both supporting factors and inhibiting factors. Researchers in determining informants are based on purposive sampling technique that determines the number of informants based on certain considerations such as the mastery of information and data required, in addition to the problems studied. Informants who can provide information about the object of study studied is the management of natural resource, village head, head of the hamlet, the head of farmer groups, farmers community. The researcher chose the respondents because they were directly involved with irrigation management. information that researchers get both secondary and primary data 100 percent of the informants that researchers select.

\section{RESEARCH DESCRIPTION}

Manis Raya Village has an area of 6,259 ha. Administratively, Manis Raya Village is part of Sepauk District which consists of four sub-villages such as Lepung Kedang, Suak, Sepakat, and Sepulut. One of the areas in Manis Raya Village built with irrigation is Suak. The irrigation system in Suak is a long-standing irrigation system built by the government in 1979 . This irrigation system started to irrigate the paddy fields in 1980 with 65 ha of paddy area. The majority of the people in this area is paddy farmers and rubber farmers.

\section{RESULTS AND DISCUSSION}

Community-Based Irrigation System
Management

The results of interviews with informants obtained the results of Irrigation Management in Dusun Suak which involves the community is cleaning the water divider ditch, ditch ditch and fix the leaking dam. The management is done in a self-help way within one day. Self-help organizations carried out by farmers are given in the form of wages. Irrigation management is still not well implemented, from maintenance, operation, rehabilitation, which includes water dividing ditches, main weirs, sewers. Irrigation networks and major dams often build up garbage and weeds. This happens because the concern of farmers who are still lacking, farmers have not been able to utilize irrigation water efficiently, so farmers often lack of water during the dry season and rainy season. Irrigation management in Dusun Suak Desa Manis Raya is done by farmer groups and farming communities that own paddy fields around irrigation. Maintenance and rehabilitation of major irrigation and dam networks is undertaken once a year with funds provided by the Sintang District Government. Development and management of irrigation systems should be conducted in a participatory, integrated, environmentally sound, transparent, accountable, and equitable manner [8]. Participation as one of the elements of development is a process of community adaptation to ongoing changes. Thus participation has an important position in development [9]. Explain that Irrigation is very helpful for water-use farmers in running their farms, because irrigation provides quite a variety of benefits if managed well by the community that includes meeting water needs, eliminating pests, and inhibiting the growth of weeds. If irrigation works well, water flow from upstream to downstream will run smoothly without any obstacles [10].

\section{Institutional Aspects \\ Organizational Structure}

The results of interviews with informants obtained results that Irrigation in Dusun Suak Village Manis Raya is an irrigation built by the provincial government through the Public Works Department. The P3A organization in Suak 
Hamlet was established in 1984 during the old regent period, and had been trained, but the organization did not run and eventually broke up. The new organization has not been reshaped to date. The dam guard officer who was donated by PU Pengairan has also been appointed civil servant and has not been replaced. Farmers do not propose a new establishment because if the organization does not run into the responsibility of the Village Government. Irrigation in Suak hamlet there is currently no organization like a water user farmer association (P3A) that takes care of this irrigation. However, the irrigation of Dusun Suak is administered by farmer groups and farming communities that have rice fields around irrigation. The role of farmer groups in irrigation management activities during this time is mainly related to dam repair and irrigation channel is done in mutual help every year as it rehabilitate the occasional damage by applying to the local government through proposal. Institutional P3A is a set of organizations that have provisions that govern the farming community in dribbling the opportunities available, as well as forms of activities that can be done by certain parties against other parties, and the privileges that have been granted and the responsibilities that must be they do [11]. The organizational structure is the pattern of the flow of resources within an organization that includes dimensions of size, complexity, and formalization [12].

\section{Leadership}

The leadership of P3A in Suak, Manis Raya Village within the irrigation system management from 1984 to 2002 has been running well in the utilization of water resources. P3A has contributed well in the form of manpower, advice, and thoughts. In the management, there are frequent activities which include cleaning water divider channels and water disposal channels, resolving problems that arise between farming communities, sending a report to the government when there is a damage, and giving transparency in the finance management. It is noted that P3A organization began to stop performing its roles and functions from 2003 until now. as a result, the irrigation system nowadays is not well managed. Leaders are people who can encourage or move others to work together to achieve the desired goals. The activeness of P3A group members will be determined by the chairman. In relation to the role of the head of the farmer the contact of the quality group as the group leader should be reliable to organize its members well. Leadership and institutional farmers need to be refined especially in receiving technology [13]. The development of farmers' institutions is strongly influenced by the attitude of farmers in accepting change identical to the desire of the farmers to move forward and progress towards the better. More and more farmers are welcome / open to new things such as information technology facilitating the role of peasant institutions effectively [14]. P3A groups are not yet independent. Therefore, in carrying out its role has not been effective, especially in increasing rice productivity, and less feel proud to be member of P3A group [15].

\section{Financial Administration}

Financial administration in Suak that there is no P3A organization in financial management. Finance is managed by the farming community. Support managed by farmers is the support of the government to clean the water and drainage channels. It is known about sixteen million rupiah in a year. The funds are only used to clean the drainage and drainage channels as they are very limited. The people who participate in this activity can only be given tens of thousands of rupiah per day. Farmers are also never charged for the maintenance of irrigation systems. Financial administration is very important in the management of irrigation systems because irrigation sustainability is measured by financial administration. In managing finances, P3A must be transparent both for government, private and community contributions [16]. Financial administration is a management process that involves all activities related to finance, financial reporting, and the achievement of goals for the common good. Financial management is done through the process of planning, organizing, directing, coordinating, supervising or control. In financial management must also pay attention to a number of principles namely transparency, accountability, effectiveness, and efficiency [17]. Government support continues to be needed in an effort to ease subak financial burdens in the form of subsidized production facilities, repair damaged irrigation networks and buildings, and aid in efforts to improve crops. This is due to the fact that the cost of network repair is still dominated by government assistance, but not continuously every year, while the contribution of farmers is still very small but can be given regularly every year [18]. 


\section{Articles of Association and Bylaws (AD/ART)}

The articles of association and bylaws are closely related to an organization. This contains rules on the main tasks and functions of each person in performing their duties. The existing management in Suak is only a group of farmers and it does not contain such rules on irrigation management. By that, when there is a violation in the water management, the subject is not sanctioned. Farmers utilized the water freely without any regulation. The Articles of Association (AD) and Bylaws (ART) constitute a basic rule governing the purpose, vision, mission, identity, membership status, governance between institutional members and the rules governing within an organization. The existence of AD / ART is important in an organization, because the organization is not just an association, but a society that has clear goals to achieve together, discuss identity and membership, and clear inter-member relationships. The absence of $A D$ / $A R T$ in an organization is a sign that a collection does not have a clear orientation. So that the activity also has no direction and can not be said good association or organization. Whereas an organization should have a clear achievement and output so that what is planned can be achieved [19].

\section{Human Resources Aspects Education}

Formal education is the quality of human resources. The quality of human resources is certainly not merely related to the ability of academic course, but with the ability of a person in responding to the environmental changes. The higher the level of education, the better the response to the problem of life especially for the sustainability of irrigation. Education level affects the society which, in the end, will create a social change. Social change is a form of innovation associated with all aspects of human life to improve the welfare of society. On average, farmers in Suak have a formal education which consistsof graduates of elementary school, junior high school, and senior high school. However, it is also known that some of them did not attend formal school. Education does not prevent them from doing their activities as farmers. These farmers do not have to have a formal education to apply technology and skill in farming because they already get the knowledge traditionally from generation to generation. The involvement of farmers in the management of irrigation systems is also influenced as well as the situation and condition of the groups and surrounding communities. The involvement of farmers in the management of irrigation systems is also influenced by their own abilities as well as the situation and condition of the groups and surrounding communities. Ability is seen from the workers who are still able to work, because farmers have a hamlet age is still relatively young between $26-50$ years. Attitudes and participation of farmers on the intensification of food crops through supra insus, which states that the level of formal education is significantly related to the level of farmer participation [20]. Education is the basis for self-development and the ability to utilize all available means the higher the education the higher the productivity of work [21]. Education of farmers Dusun Suak Village Manis Raya can be seen in Table 1.

Table 1. The Education Level in Suak, Manis Raya Village 2017

\begin{tabular}{ccc}
\hline No. & Educational Level & Total \\
\hline 1 & Did not attend school & 13 \\
2 & Elementary School & 18 \\
3 & Junior High School & 19 \\
4 & Senior High School & 24 \\
& Total & 74 \\
\hline
\end{tabular}

Source: PPL of Manis Raya Village 2017

\section{Social-Economy}

The socio-economic aspect is a measure of one's ability to fulfill one's needs as measured by income, education, and daily activities. Economically, the farmers in Suak, Manis Raya Village earn low income by relying only on livelihoods like cultivating and rubber farming. Farmers are not able to buy the tools to support their own agricultural activities so that when they want to manage their fields, they have to hire other farmers' tools. Farmers' rice income in Suak ranges from $600(\mathrm{~kg})-3$ (tons) per year with two yearly cropping patterns. Socially, farmers still implement mutual assistance in managing the farming activities and maintaining irrigation system although they also provided with fees. Farmers' awareness in maintaining irrigation system is still low in which they always expect assistance from the government. Revenue is income in the form of money during a certain period. Therefore, income can be interpreted as all income or cause the increase of a person's ability, whether used for consumption or for savings. With such income used for the 
necessities of life and to achieve satisfaction [22]. Socio-economic is the position or position of a person in a community group determined by the type of economic activity, income level, education level, residence and occupation within the organization. Socioeconomic characteristics will also be influenced by many things, which will lead to differences between the socioeconomic conditions of a person and another person [23]. The life of the social economy of the farmers in Suak Village Manis Raya can be seen in Table 2.

Table 2. Population Data Based on Land Ownership in Suak, Manis Raya Village

\begin{tabular}{cccc}
\hline No. & $\begin{array}{c}\text { Land Area } \\
\text { (ha) }\end{array}$ & $\begin{array}{c}\text { rice } \\
\text { income } \\
\text { (ton) }\end{array}$ & $\begin{array}{c}\text { Population } \\
\text { (KK) }\end{array}$ \\
\hline 1 & 1,00 & $600 \mathrm{~kg}-1$ & 17 \\
2 & 2,00 & ton & 19 \\
& & $2-3$ tons
\end{tabular}

$\begin{array}{ll}\text { Total } & 36\end{array}$

Source: PPL of Manis Raya Village 2017

\section{Work Ability}

Results of interviews with informal results obtained the ability of work is very important in life both in the organization and in a community. This can be said to show the quality of a man/woman itself. The development and management of irrigation system can work well if the farming community has the ability to manage it. The ability of farmers is very influential on the maintenance of irrigation system. In Suak, the community supports the farming activity and maintains the irrigation system based on their own ability. The farmers of Dusun Suak have the average ability to manage irrigation system, they are able to manage minimal finances with budget of approximately 16 million, able to interact in groups seen when present at the meeting, the farmer express their opinion, and able to solve the problems in the group kinship, and experience and understanding in organizing quite well, because it has an average education high school graduation. Competent is a functional skill required to perform a task at a job according to a set standard [24]. The success of farmers in farming is closely related to the competence of agribusiness owned by farmers in managing their farm business. Agribusiness competence is the ability of farmers to think, behave and act in planning farming to gain profits in farming, establishing cooperation between agricultural subsystems, managing post-harvest food to gain agricultural product added value, and realizing sustainable agriculture activities [25].

\section{Facilities and Infrastructure Aspects} Availability of Facilities and Infrastructure The availability of facilities and infrastructure is very influential on agriculture in the economic empowerment of the community itself. This certainly affects the harvest results. Local Government, Public Works Service (Water Resources Division), and Department of Agriculture shall pay attention to facilities and infrastructure that support the activities of farming. Besides that, they also need to pay attention to the economic and ecological functions, religious values, as well as the existence of customs that live in the local community. The availability of tractors, rice thresher machines, water containers, boreholes, water, irrigation system including the main building and dividing door is still very limited. There are some leaks at the main building so that it does not work optimally. It is calculated that it might able to hold water only for three days. The dividing door in the downstream area built by Public Works Service (Water Resources Division) is higher so that the water cannot flow to irrigate the paddy fields in downstream. Moreover, there are only two tractors to plow the fields. This makes the farmers often experience struggle when they want to use it and often create a conflict between them. The rice thresher machine is also known to be only two units and all of which are out of order. Farmers have to borrow other farmer's property. The drill bore made by the government also cannot be used because it was exposed to salt wells. The infrastructure facilities that support agricultural activities in Dusun Suak Desa Manis Raya can be seen in Table 3.

Table 3. Agricultural Facilities and Infrastructure in Suak

\begin{tabular}{cccc}
\hline No. & $\begin{array}{c}\text { Facilities and } \\
\text { Infrastructure }\end{array}$ & Total & Desc. \\
\hline 1 & Dam/irrigation system & 8 & Good \\
2 & Water divider channel & 3.000 & Good \\
3 & Water disposal channel & 1.500 & Good \\
4 & Tractor & 2 & Good \\
5 & Hoe & 16 & Good \\
6 & Boreholes & 4 & Good \\
7 & Chopper & 60 & Good \\
8 & Jagged sickle & 60 & Good \\
9 & Rice thresher machine & 2 & broken \\
\hline Source: Monographic of Manis Raya Village 2017
\end{tabular}


Based on the table above, the facilities and infrastructure for the availability of water in the form of water container have not been provided. This often causes a failure in farmers' crop during the dry season. Infrastructure and facilities is one important factor in the process of farming, including irrigation infrastructure. irrigation infrastructure determines the availability of water that has a direct impact on the quality and strength of crops, especially rice crops. Water supply from upstream to downstream requires adequate irrigation facilities and infrastructure. The facilities and infrastructure may include dams, primary canals, secondary channels, building blocks, measuring buildings, and tertiary channels and farm-level channels (TUT). Damage to one of the irrigation buildings will affect the performance of existing irrigation systems, resulting in reduced efficiency and effectiveness of irrigation [26].

\section{Management and Utilization of Facilities and Infrastructure}

The management and utilization of facilities and infrastructure are very important to be done because it is a container to assist farmers in managing the fields so that it must be managed optimally. Farmers in Suak, Manis Raya Village have not been able to utilize the existing facilities and infrastructure such as tractors, rice threshing machines, water divider channels, water disposal channels, and major dam. Farmers are still struggling with tractors. The broken rice threshing machine cannot be used again. There are a lot of garbage and overgrown weeds in the irrigation system. The use of water is still free without any regulation so that a delay in rice cultivation often occurs. Irrigation networks continue to function should be supported by all stakeholders considering the facilities and infrastructure have a positive impact on agricultural activities, including no delay in rice cultivation, not late in plowing rice fields, and the lack of seizure of the use of facilities and infrastructure, so that conflicts between peasant communities can be avoided. The progress and active role of the community in the maintenance of irrigation canals and buildings independently, as well as knowledge of efficient water use should be encouraged and improved through the development of Water User Farmers' Union (P3A) [27].

Irrigation System Aspects Irrigation System Operation
Irrigation network operations carried out by the management of farmer groups by involving community participation. There is no policy of regulating irrigation water to prioritize rice water. Water is still freely channeled by farmers. Among other things irrigation water that flowed into fish pond that is not regulated properly. The distribution of water for farmer members can be distributed evenly if there is a weir guard officer responsible for managing water and cooperation among farmers. Operation is an activity that is carried out in a planned, coordinated manner, to utilize the infrastructure optimally with the target in order to provide services that are expected to achieve the ultimate goal. With such activities the efforts of operating the doors to drain the water until the location of the beneficiaries can be fairly and equitably accepted [28]. Basically, water needs to be arranged for its grant to the right amount of land and time. With any technology, to properly manage irrigation water, it is necessary to carry out a series of activities involving all aspects of operations and maintenance, ranging from mobilization to cleaning, repair and conflict resolution on water sharing and planning for the next planting season [29].

\section{Irrigation System Maintenance}

Maintenance of irrigation networks in Dusun Suak is done once a year with the help of funds provided by the local government. Maintenance is done jointly by people who have rice fields around irrigation. The funding provided by the local government for the maintenance of irrigation networks is sometimes insufficient so that irrigation networks often occur in the accumulation of garbage and weeds and leaks. P3A institutional constraints in maintaining and maintaining irrigation networks due to lack of cooperation among group members, limited funding sources, awareness of members of low irrigation networks. Community participation is a tool that can bring about changes in social forces within a community organization that have an impact on success in building irrigation networks at various levels of the village. The greater the public participation in operations and maintenance activities on irrigation networks the irrigation network will function properly [30].

\section{Irrigation System Rehabilitation}

The condition of irrigation dam of Dusun Suak has been leaked in the last two years, the dam has also been shallow so that water 
reservoir is also limited, and much grass. The dam has not functioned as before, because the leaking dam has not been repaired yet. The dam was repaired after funding from the local government. The farming community has applied for the rehabilitation of the dam but there has been no response. Irrigation network management can work well if there is cooperation between government and society. The government should provide support for irrigation to create food self-help. To realize the sustainability of irrigation system is done by developing and managing irrigation system, that is by construction of new irrigation network and / or improvement of existing irrigation network and doing activities which include operation, maintenance and rehabilitation of irrigation network in irrigation area. Irrigation management as an effort to utilize irrigation water covering operation and maintenance, security, rehabilitation, and irrigation improvement. Irrigation management is conducted by prioritizing the interests of the farming community and by placing water user farmers associations as the key decision makers and actors in irrigation management that are their responsibility. To achieve this, empowerment of water user farmer associations is continuous and sustainable [31].

\section{Farmers' Participation}

Farmers' participation is intended to develop the social character and enhance the sense of belonging, responsibility, and capability of the community in order to improve the efficiency and effectiveness of the irrigation system sustainability. The participation of farmers in Suak, Manis Raya Village in the management of its irrigation system is in the form of mind, energy, and time-based on funding transparency. The participation is carried out through the direct involvement of the community in cleaning the water divider channels and water disposal channels. Such participation is rewarded with fees. Unfortunately, it is known that farmers' participation is still very poor because they only want to work if there is a help from the government. The farmers do not want to do such mutual assistance in cleaning the channels because it hampers the irrigation of their fields. Participation as one of the elements of development is a process of community adaptation to ongoing changes. Thus participation has an important position in development [32]. Community involvement with activities concerned with the public interest by contributing ideas, material and energy thoughts including mind participation, material participation and labor participation [33]. Some of the characteristics of participation include: positive, creative, critical, corrective, constructive and realistic [34].

\section{The Inhibiting Factors of Community-Based Irrigation Management}

There are several inhibiting factors in the irrigation management, such as no P3A organization, poor farmer participation, limited government assistance, and no clear rules from the Local Government of Sintang Regency. Consequently, the irrigation system in some villages in Sepauk District does not work optimally. There are some abandoned irrigation systems because most of the paddy fields in Sepauk District use a rain-fed. One of the factors that need attention in community participation is education factor, with adequate level of education, individual / society will be able to give expected participation. Another thing that hampers community participation is the job problem. Livelihood is one of the most influential factors in community participation in the management of sustainable irrigation systems [35].

\section{CONCLUSION}

Based on the results of research that has been done on irrigation in Dusun Suak Village Manis Raya then it can be concluded:

(1) Irrigation management in Suak Village Manis Raya Village has not been managed well by P3A and the government, seen from irrigation networks that often accumulate rubbish, weeds, main dams are leaking and farmers often experience water shortages during the dry season. (2) Inhibiting factors for irrigation management in Suak Desa Manis Raya is the absence of P3A organizations that play an active role in irrigation management both for water distribution and maintenance of irrigation networks, lack of farmers' participation in maintaining irrigation networks, and limited funding provided by the government for irrigation management.

\section{SUGGESTION}

Based on the above conclusions, the researcher suggests some things as follows: 
(1) P3A organizations need to be established which have legal clarity. (2) Local governments must pay attention to facilities that support agricultural activities, such as the construction of ponds, rehabilitation of large dams. (3) It is necessary to increase the participation of farmers' communities through existing organizations, namely farmer groups. (4) Building cooperative relationships between government and society.

\section{ACKNOWLEDGEMENT}

Thank you, the authors convey to the Manis Raya Village Chief and staff, the head of the Suak Hamlet, farmer groups and the Suak Hamlet farming community who have helped the author in providing information and data on irrigation management in Suak Village, Manis Raya Village.

\section{REFERENCE}

[1]. Ismaya. T, Jaka Sulaksana, dan Deles Hadiana. 2016. "Pengembangan dan Pengelolaan Jaringan Irigasi Untuk Meningkatkan Hasil Produksi Pendapatan Usahatani Padi Sawah". Dalam Jurnal IImu Pertanian dan Perternakan, Vol. 4, No. 2, Desember 2016.

[2]. Yenifa. Fitra, Idris, dan Hasdi Aimon. 2011. "Faktor-Faktor Yang Mempengaruhi Partisipasi Anggota P3A Dalam Pengelolaan Irigasi Pada Water Resources and Irrigation Sector Management Program (WISMP) di Kecamatan Kuranji Kota Padang".

[3]. Prosdsiding Lokarya Nasional Jaminan Air Bagi Petani. 1999. Bandung: Pusat Dinamika Pembangunan (PDP) Unpad.

[4]. Zamroni, A., Hadiani, R dan Sobriyah, 2016. "Skala Prioritas Pemeliharaan dan Rehabilitasi Jaringan Irigasi Sederhana". Dalam Jurnal UMJ, 2016.

[5]. Budiyono, A, 2004. Pengantar Manajemen. Yogyakarta: Graha IImu.

[6]. Isharyanto, S., Jatmiko, A.H dan Adriana, G.F, 2016. “Model Kapasitas Birokrasi Untuk Pengembangan Integritas Perkumpulan Petani Pemakai Air (P3A) Dalam Rangka Pencapaian Kedaulatan dan Keamanan Pangan Lokal". Dalam Jurnal Fakultas Hukum, Vol. 5, No. 1, Januari-April 2016.

[7]. Akrab. 2017. Penguatan Kelembagaan Perkumpulan Petani Pemakai Air Dalam Pengelolaan Irigasi Awo di Sulawesi Selatan. Disertasi Doktor, Program Pascasarjana Institut Pertanian, Bogor
[8]. Mintara, E, 2013. “Pengelolaan Air Tanah Untuk Irigasi Berbasis Masyarakat di Desa Pangkul Kecamatan Cambai Kota Prabumulih. Dalam Jurnal Prosiding Seminar Nasional Pengelolaan Sumberdaya Alam dan Lingkungan, 2013.

[9]. Sugiyono, 2014. Metode Penelitian Pendidikan: Pendekatan Kuantitatif, Kualitatif dan R\&D. Bandung: Alfabeta.

[10]. Kodoatie, J.R dan Roestam, S, 2007. Pengelolaan Sumber Daya Air Terpadu. Yogyakarta: Andi.

[11]. Rahadiani, D, 2014. Partisipasi Masyarakat Sekitar Danau Baratan Dalam Konservasi Sumber Daya Air. Tesis Magister Teknik Sipil, Program Pascasarjana Universitas Udayana, Denpasar.

[12]. Torang, S, 2016. Organisasi dan Manajemen. Bandung: Alfabeta.

[13]. Yanti, D.R, 2015. “Dinamika Kelompok Perkumpulan Petani Pemakai Air di Lahan Rawa Lebak". Dalam SEPA, Vol. 11 No.2 Februari 2015.

[14]. Cahyono, Tjokropandojo, S dan Sawitri, D, 2013. "Peran Kelembagaan Petani Dalam Mendukung Keberlanjutan Pertanian Sebagai Basisi Pengembangan Ekonomi Lokal". Dalam Jurnal Perencanaan Wilayah Kota B SAPPK, Vol. 2, No. 1, ITB. Bandung 2013.

[15]. Kasandra, L.A., Sumono dan Harahap, A.L, 2016. "Evaluasi Kinerja Operasi dan Pemeliharaan Sistem Irigasi Suka Damai Kecamatan Sei Bamban Kabupaten Serdang Berdagai". Dalam Jurnal Rekayasa Pangan dan Pertanian, Vol.4, No 3, 2016.

[16]. Rina, Y., Noorginayuwati, M, Noor, H, Syahbuddin, B.R, 2011. "Efektifitas Kelembagaan Pengelolaan Air Existing di Lahan Pasang Surut". Balittra, Balai Besar Penelitian dan Pengembangan Sumberdaya Lahan.

[17]. Cahyo, A dan Kamatri, 2016. Defenisi dan fungsi manajemen administrasi keuangan.Modul Pembelajaran, Program Studi S1 Pendidikan Administrasi Perkantoran, Fakultas Ekonomi Universitas Negeri Malang.

[18]. Purwoko, A., Zulkarnain, M dan Ardiansyah, 2011. "Hubungan Faktor-Faktor Internal dan Eksternal Dengan Tingkat Partisipasi Anggota Kelompok Petani Pemakai Air (Kp2a)". 
[19]. Safitri, D, (Ed), 2017. Manajemen Pendidikan. Yogyakarta: Deepublish Budi Utama.

[20]. Wulandari, 2013. Kondisi Sosial Ekonomi Petani Padi Sawah di Kelurahan Mangalli Kecamatan Pallangga Kabupaten Gowa.Skripsi Sarjana, Fakultas IImu Sosial dan IImu Politik Universitas Hasanuddin Makassar.

[21]. Phahlevi, R, 2013. Faktor - Faktor Yang Mempengaruhi Pendapatan Petani Padi Sawah di Kota Padang Panjang. Skripsi Sarjana, Program Studi Ekonomi Pembangunan, Fakultas Ekonomi Universitas Negeri Padang.

[22]. Fitriani, I, 2016. Karakteristik Sosial Ekonomi Petani Kecil di Desa Poncowarno Kecamatan Kalirejo Kabupaten Lampung TengahTahun 2015. Skripsi Sarjana, Fakultas Keguruan dan Ilmu PendidikanUniversitas Lampung, Bandar Lampung.

[23]. Manyamsari, I, 2014. “Karakteristik Petani dan Hubungannya Dengan Kompetensi Petani Lahan Sempit". Dalam Jurnal Agrisep, Vol 15, No. 2, 2014.

[24]. Rangkuti, W.S, 2015. "Potensi dan Kendala Kelembagaan Perkumpulan Petani Pemakai Air (P3A) Dalam Operasi dan Pemeliharaan Irigasi Pada Daerah Irigasi Sungai Ular Propinsi Sumatera Utara. Dalam Jurnal Teknik Sipil, Vol. 4, No. 3, Agustus 2015.

[25]. Ludiana. Wilhelmus, B dan Tri M.W.S, 2015. "Evaluasi Kinerja Jaringan Irigasi Bendungan Tilong Kecamatan Kupang Tengah Kabupaten Kupang". Dalam Jurnal Teknik Sipil, Vol. IV, No. 1, April, 2015.

[26]. Wahyudhi, A.M., Norken dan Suputra, K, 2015. "Partisipasi Stakeholders Dalam Operasi dan Pemeliharaan Jaringan Irigasi Pada Daerah Irigasi Unda di Kabupaten Klungkung". Dalam Jurnal Spektran, Vol.3, No. 2, Juli 2015.

[27]. Yuliartha, Norken, N dan Harmayani, D.K, 2018. "Partisipasi Subak dan Pemerintah Terhadap Operasi dan Pemeliharaan Pasca Pembangunan Infrastruktur Disimp li Pada Daerah Irigasi Gadon Das Sungi di Kabupaten Tabanan". Dalam Jurnal Spektran, Vol. 6, No. 1, Januari 2018.

[28]. Kesuma, A.W.M., Suardi, O.P.D dan Wijayanti, U.P, 2017. "Realisasi Bantuan Rehabilitasi Jaringan Irigasi Tersier Kepada Subak Margasengkala, Desa Bedulu, Kecamatan Blahbatuh, Kabupaten Gianyar".
Dalam Jurnal Agribisnis dan Agrowisata, Vol. 6, No. 3, Juli 2017.

[29]. Surnayo, M.T., Tjoek, W dan Aris, H, 2007. Pengelolaan Sumber Daya Air (Konsep dan Penerapannya). Malang: Bayumedia Publishing. 